\title{
Pendidikan Kesehatan Patuh Minum Obat: Jurnal Refleksi
}

\section{Febri Warni Hulu}

febriwarnihulu@gmail.com

Puji syukur saya ucapkan kepada Tuhan Yang Maha Esa, dimana karena berkat dan kasihnya saya mampu melakukan intervensi yaitu pendkes pemberian obat pada pasien. Awalnya saya rasa pasien akan menolak, apalagi pasien yang ingin saya terapkan tindakan ini adalah pasien baru dengan masalah keperawatan jiwa yaitu halusinasi pendengaran. Pasien ini berkata bahwa dia sudah bosan minum obat, dan sebelum kembali masuk rumah sakit lagi, pasien memang jarang minum obat, alasannya karena tidak ada yang mengawasi dia untuk minum obat. Pasien berkata dia lelah minum obat, penyakit nya juga tidak sembuh.

Halusinasi merupakan keadaan seseorang mengalami perubahan dalam pola dan jumlah stimulasi yang diprakarsai secara internal atau eksternal disekitar dengan pengurangan berlebihan, distorsi, atau kelainan berespon terhadap setiap stimulasi dan halusinasi juga merupakan perubahan dalam jumlah dan pola dari stimulasi yang diterima dan disertai dengan penurunan berlebihan distorsi atau kerusakan respon beberapa stimulasi. (Pardede, 2016)

Pasien yang sudah keluar dari rumah sakit maka tugas perawat diganti kan oleh keluarga. Jika keluarga tidak memantau klien saat minum obat maka klien mungkin tidak akan minum obat secara teratur. (Pardede, 2021). Pendidikan kesehatan merupakan bagian dari promosi kesehatan yaitu suatu prosesuntuk meningkatkan kemampuan masyarakat dalam memelihara dan meningkatkan kesehatan dan tidak hanya mengkaitkan diri pada peningkatan atau memperbaiki lingkungan (baik secara fisik maupun non fisisk) dalam rangka memelihara dan meningkatkan kesehatan mereka (Pardede, 2016). 
Pendkes ini saya berikan kepada pasien yang mengalami halusinasi pendengaran, pasien berkata sering mendengar suara suara yang berbisik, pasien sudah mencoba untuk menutup telinga dengan tangan maupun bantal, namun kadang suara ittu terus muncul, biasanya sering muncul setelah maghrib. Saat saya bertanya mengenai kepatuhan minum obat, pasien berkata dia kadang membuang obat yang diberikan perawat, alasannya karena dia tak juga sembuh, makanya dia rasa bahwa oba pun tidak berpengaruh. Namun setelah saya menjelaskan manfaat dari patuh minum obat, pasien akhirnya paham tentang apa tujuan pemberian obat dan tahap kerja obat. Sehingga pasien berkata tidak akan membuang obat lagi. Setelah melakukan pendkes tersebut, pasien sudah tidak membuang obatnya lagi.

Saya bangga sekali dapat menyampaikan pendkes ini, saya berharap semoga ilmu yang saya dapat ini menjadi bekal yang berharga bagi saya kedepannya. 


\section{Referensi}

Mubin, M. F., \& Livana, P. H. (2019). Hubungan Kepatuhan Minum Obat Dengan Kekambuhan Pasien Skizofrenia Paranoid. Jurnal Farmasetis, 8(1), 21-24.

Pardede, J. A., \& Siregar, R. A. (2016). Pendidikan Kesehatan Kepatuhan Minum Obat Terhadap Perubahan Gejala Halusinasi Pada Klienskizofrenia. Mental Health, 3(1).

Pardede, J. A., Siringo-ringo, L. M., Hulu, T. J., \& Miranda, A. (2021). Edukasi Kepatuhan Minum Obat Untuk Mencegah Kekambuhan Orang Dengan Skizofrenia. Jurnal Abdimas Mutiara, 2(2), $1-5$. 